Hence

$$
\begin{aligned}
|\eta| & =\left|-a \int_{0}^{\tau} \epsilon(x) d x\right|=\left|\sum_{\alpha=1}^{\alpha=[T / \tau]} \epsilon(\alpha \tau)-a \int_{[T / \tau] \tau}^{T} \epsilon(x) d x\right| \\
& \leqq M+2 M\left(1-e^{-a \tau}\right)+2 M\left(1-e^{-a \tau}\right)^{2}+\cdots+a M\left(T-\left[\frac{T}{\tau}\right] \tau\right)\left(1-e^{-a \tau}\right)^{[T / 2 \tau]} \\
& \leqq M\left(2 e^{a \tau}-1\right)+a M\left(T-\left[\frac{T}{\tau}\right] \tau\right)\left(1-e^{-a \tau}\right)^{[T / 2 \tau]} .
\end{aligned}
$$

From (3) it can be seen that $M=a \tau /(1+a \tau)$ and (4) follows.

The inequality (4) is very satisfactory and shows that even for large values of $a \tau$ the quantity $\eta$ will be very small compared to $a T /(1+a \tau)$ even if $T$ is only a few minutes.

\title{
CORRECTIONS TO OUR PAPER
}

\section{STABILITY OF COLUMNS AND STRINGS UNDER PERIODICALLY VARYING FORCES*}

Quarterly of Applied Mathematics, 3, 215-236 (1943)

\begin{tabular}{|c|c|c|}
\hline$\alpha\left(C_{0}\right)$ & for & read \\
\hline $\begin{array}{l}1.6 \\
1.8 \\
7.6 \\
9.2\end{array}$ & $\begin{array}{l}-0.77898 \\
-0.92281 \\
-5.71537 \\
-7.11974\end{array}$ & $\begin{array}{l}-0.77897 \\
-0.92282 \\
-5.71538 \\
-7.11975\end{array}$ \\
\hline
\end{tabular}

By S. LUBKIN and J. J. STOKER (New York University)

\begin{tabular}{|c|c|c|}
\hline$\alpha\left(C_{1}\right)$ & for & read \\
\hline 3.6 & -2.32402 & -2.32401 \\
\hline
\end{tabular}

The following errors were found in the tables printed on pp. 232-235.

\begin{tabular}{|c|c|c|}
\hline$\alpha\left(S_{1}\right)$ & for & read \\
\hline $\begin{array}{r}0.8 \\
1.4 \\
4.4 \\
7.6 \\
11.0\end{array}$ & $\begin{array}{r}0.55906 \\
0.63015 \\
-0.29781 \\
-2.08644 \\
-4.29436\end{array}$ & $\begin{array}{r}0.55406 \\
0.63016 \\
-0.29780 \\
-2.08648 \\
-4.29437\end{array}$ \\
\hline
\end{tabular}

\begin{tabular}{|c|c|c|}
\hline$\alpha\left(C_{2}\right)$ & for & read \\
\hline $\begin{array}{r}0.6 \\
3.4 \\
20.0\end{array}$ & $\begin{array}{r}1.12806 \\
2.01478 \\
-5.05198\end{array}$ & $\begin{array}{r}1.12810 \\
2.01477 \\
-5.05199\end{array}$ \\
\hline
\end{tabular}

\begin{tabular}{|c|c|c|}
\hline${ }_{\beta} \alpha\left(C_{3}\right)$ & for & read \\
\hline $\begin{array}{l}0.6 \\
1.0 \\
2.2 \\
2.8 \\
5.6\end{array}$ & $\begin{array}{l}2.26622 \\
2.28515 \\
2.31495 \\
2.29660 \\
1.85589\end{array}$ & $\begin{array}{l}2.26621 \\
2.28516 \\
2.31493 \\
2.29661 \\
1.85591\end{array}$ \\
\hline
\end{tabular}

\begin{tabular}{|c|c|c|}
\hline \multicolumn{1}{|c|}{${ }^{\alpha\left(S_{2}\right)}$} & for & read \\
\hline $\begin{array}{c}3.8 \\
6.8\end{array}$ & -0.00468 & -0.00464 \\
8.4 & -2.60383 & -1.60379 \\
& & \\
\hline
\end{tabular}

* Received Aug. 16, 1946. 


\begin{tabular}{|c|c|c|}
\hline$\alpha\left(S_{3}\right)$ & for & read \\
\hline $\begin{array}{l}1.6 \\
2.0 \\
3.8 \\
4.4 \\
5.6\end{array}$ & $\begin{array}{l}2.51308 \\
2.66777 \\
3.46578 \\
3.69216 \\
4.01149\end{array}$ & $\begin{array}{l}2.51309 \\
2.66776 \\
3.46579 \\
3.69215 \\
4.01150\end{array}$ \\
\hline
\end{tabular}

\begin{tabular}{|r|c|c|}
\hline \multicolumn{1}{|c|}{$\alpha\left(S_{4}\right)$} & for & read \\
\hline 1.6 & 4.07660 & 4.07659 \\
1.8 & 4.09433 & 4.09432 \\
2.4 & 4.15212 & 4.15211 \\
2.6 & 4.17199 & 4.17200 \\
12.0 & 3.38817 & 3.38820 \\
\hline
\end{tabular}

\begin{tabular}{|c|c|c|}
\hline$\alpha\left(C_{4}\right)$ & for & read \\
\hline $\begin{array}{l}1.6 \\
2.4 \\
2.8 \\
4.8 \\
6.0\end{array}$ & $\begin{array}{l}4.09776 \\
4.24889 \\
4.35867 \\
5.18127 \\
5.74803\end{array}$ & $\begin{array}{l}4.09777 \\
4.24891 \\
4.35865 \\
5.18128 \\
5.74303\end{array}$ \\
\hline
\end{tabular}

\begin{tabular}{|c|c|c|}
\hline$\beta$ & for & read \\
\hline 16.0 & 6.52721 & 6.52709 \\
& & \\
\hline
\end{tabular}

Column headings for $\alpha\left(S_{6}\right)$ and $\alpha\left(S_{6}\right)$ are interchanged on p. 234.

\begin{tabular}{|r|r|r|}
\hline \multicolumn{1}{|c|}{$\alpha\left(S_{6}\right)$} & \multicolumn{1}{|c|}{ for } & \multicolumn{1}{c|}{ read } \\
\hline 0.4 & 6.25333 & 6.25334 \\
2.2 & 6.35487 & 6.35488 \\
3.2 & 6.48591 & 6.48590 \\
4.8 & 6.86185 & 6.86180 \\
5.2 & 6.99394 & 6.99396 \\
5.6 & 7.14093 & 7.14116 \\
20.0 & 10.33749 & 10.33744 \\
\hline
\end{tabular}

\begin{tabular}{|c|c|c|}
\hline$\widehat{\beta}_{\beta}^{\alpha\left(S_{6}\right)}$ & for & read \\
\hline $\begin{array}{r}3.8 \\
5.2 \\
16.0 \\
20.0\end{array}$ & $\begin{array}{r}9.20714 \\
9.38281 \\
10.59848 \\
10.35813\end{array}$ & $\begin{array}{r}9.20713 \\
9.38279 \\
10.59849 \\
10.35825\end{array}$ \\
\hline
\end{tabular}

\section{BOOK REVIEWS}

Theory of Structures. By S. Timoshenko and D. H. Young. McGraw-Hill Book Company, Inc., New York and London, 1945 . xiv +488 pp. $\$ 5.00$.

This valuable addition to text-book literature is based on the senior author's earlier volume, published in Russia in 1926 (S. Timoshenko, Theory of Structures, Leningrad). The book is intended for engineering students with some background in mechanics. The keynote of this book is that familiarity with the general principles of mechanics is indispensable to a thorough understanding of the analysis of stresses in trusses and frames. For this reason two of the nine chapters are devoted to a comprehensive recapitulation of the rudiments of plane statics and of such general theorems on elastic systems as the Principle of Least Work, Castigliano's Theorem, Maxwell's Reciprocal Theorem, etc.

As one would expect from the authors, the book is very clearly written. It abounds in carefully constructed figures and diagrams, and contains a wealth of well-graded problems.

The chapter headings are as follows: Elements of Plane Statics, Statically Determinate Plane Trusses, Influence Lines, Statically Determinate Space Structures, General Theorems Relating to Elastic Systems, Deflection of Pin-jointed Trusses, Statically Indeterminate Pin-jointed Trusses, Beams and Frames, Arches.

This book will be of considerable interest to structang engineers and will be welcomed by the teachers of mechanics and theory of structures. 